\title{
The Market for Corporate Tax Knowledge
}

\author{
John Hasseldine* \\ University of Nottingham \\ Kevin Holland \\ University of Southampton \\ Pernill van der Rijt \\ University of Nottingham
}

This is the authors' copy of the paper subsequently published in Critical Perspectives on Accounting Volume 22, Issue 1, January 2011, Pages 39-52, ISSN 1045-2354, doi:10.1016/j.cpa.2010.06.019 $\quad$ http://www.sciencedirect.com/science/article/B6WD45161PBY-1/2/82b1910210fc13e8e36e2e69d2c8d04e

* Corresponding author

E-mail addresses: john.hasseldine@ nottingham.ac.uk

\section{Acknowledgement}

Earlier versions of this paper were presented at annual meetings of the Taxation Research Network (University of Sheffield, 2007) and the Academy of Management (Anaheim, 2008) and at workshops at Victoria University of Wellington and the University of New South Wales. We especially thank Lynne Oats and two anonymous reviewers as well as conference and workshop participants for their constructive comments. We also gratefully acknowledge financial assistance from the ACCA. We are particularly grateful to the interview participants. 


\title{
The Market for Corporate Tax Knowledge
}

\begin{abstract}
A growing international literature advocates the importance of trust and co-operation in tax administration compared to the more traditional 'adversarial' approach. Yet, the global financial crisis has led to renewed interest in corporate tax planning and 'unacceptable' tax avoidance with a focus on the role of intermediaries such as accounting firms. This paper explores how developments in tax legislation are captured by companies and incorporated into their tax knowledge. We draw on prior literature in knowledge management, the role of accounting firms and tax administration and use a qualitative approach to investigate and describe the relationships between accounting firms, corporate taxpayers and revenue authorities, specifically the UK HM Revenue and Customs (HMRC). Our results show that these relationships can be described in the context of a tax knowledge market comprised of a knowledge seller, knowledge brokers, and knowledge buyers. Our findings have relevance not only for all three parties, in particular for the challenges facing knowledge brokers - but also to tax agencies and international organisations, who must strike the optimal balance between co-operative tax administration and traditional approaches buttressed by tax audit enforcement.
\end{abstract}

\section{Keywords:}

accounting firms; knowledge markets; knowledge sharing; knowledge management; tax avoidance; tax legislation; tax planning 


\section{Introduction}

The global financial crisis has led to increased international attention on corporate tax planning and avoidance from leaders of the G-20 countries through to tax agencies, academics and campaigners for social justice (Global Forum, 2009; Owens, 2009; Sikka and Willmott, 2010). This current focus on tax avoidance and the use of sophisticated planning techniques, often involving offshore financial centres, reinforces a 'traditional' view on the adversarial nature of tax systems where the primary concern of policymakers is the threat to public revenue.

Counter to the social justice literature, recent work in tax administration however has focused on the importance of trust and integrity in tax systems (Braithwaite 2003; 2007; Kirchler et al. 2008). In short, this approach argues that a co-operative approach may result in improved tax compliance. Many tax agencies throughout the world now refer to taxpayers as 'customers' and provide 'services' with the objective of enabling their customers to meet various compliance obligations.

Prior research has been conducted on tax avoidance schemes and policing methods (e.g. Freedman et al. 2009; Oats and Salter, 2008) and whether such schemes are legally and/or morally acceptable, but only recently has research emerged dealing with the

relationships between the actors in the complex corporate tax environment. Exemplars include research on large corporates' relationships with tax agencies such as HM Revenue \& Customs (HMRC) in the UK and the Internal Revenue Service (IRS) in the US (Oats and Tuck, 2008; Mulligan, 2008; Mulligan and Oats, 2009; Toumi, 2008; Tuck 2007).

This extant literature while noting the tensions between the co-operative and adversarial approaches has not examined an important pre-cursor. Indeed, earlier interpretive studies have described modes of organising knowledge within professional accounting firms (Empson, 2001; Morris and Empson, 1998), contextualizing knowledge (Lowe, 2004) or 
called for more research on accounting firms (Cooper and Robson, 2006; Gibbins and Jamal, 1993). Scholars and policy-makers must therefore be cognisant that before avoidance, legitimate tax planning or even mere 'passive' compliance can take place; companies must effectively develop and manage tax knowledge. Accordingly, sharing, creating, and applying tax knowledge is a topic worthy of study as part of the process of better understanding the contextual environment within which accounting firms operate. It is also likely to be key to corporate taxpayers not running foul of revenue agencies and to be able to implement competent tax planning and compliance. It is in the wider interests of society that unnecessary disputes founded on incomplete understandings of the application of the tax rules be avoided as much as possible. It is also in the interests of wider society for tax agencies to discharge their tax administration duties as effectively as possible, not only in terms of monetary cost, but also in terms of the intangible benefits flowing from the smooth running of the tax system. It might thus, be expected ex ante, that effective tax knowledge exchange and co-operation could lead to benefits to tax administration in general.

While knowledge management is multidisciplinary and has established a relatively strong position in disciplines such as economics, management, organisation studies etc., in tax accounting research there is a dearth of published work. The primary contribution of this paper is to fill this gap and explore how developments in tax legislation are captured by companies and incorporated into their tax knowledge. The institutions that play a crucial role in the implementation of tax knowledge are HMRC, accounting firms and corporate taxpayers. While tensions obviously exist, these organisations are not necessarily competitive towards each other. Instead, they have a mutual dependency in enabling the successful implementation of new legislation, and are considered to be willing to share knowledge for this purpose. The tax knowledge market described in this paper can be distinguished from the general management consultancy knowledge market, as described by Morris and Empson 
(1998), as there is a compulsory aspect for corporate tax knowledge buyer participation with significant penalties for error i.e. there is no choice about whether to be a taxpayer!

This paper makes an academic contribution by exploring tax related processes of knowledge sharing between organisations and the implementation and utilisation of knowledge within each of these organisations. Relevant themes that are addressed are the way these organisations share and incorporate tax knowledge, and under which conditions they do so. Thus the paper extends prior discussions of tax knowledge in more specific settings that, hitherto, is often restricted to one player in the market (Bonner et al. 1992; Oats and Tuck, 2006; 2008). The special setting of tax expertise within accounting firms has also arguably been overlooked in the literature dealing with professional firms (Empson, 2001), and so the paper also contributes to scholarly work in that area.

Our results and discussion have practical relevance for tax agencies, accounting firms, and corporate taxpayers. For example, more insight into the process of understanding, assimilating and implementing changes in tax legislation by accounting firms and corporate taxpayers could result in applications of tax law as intended by policy makers. A relatively recent example was the introduction in 2000 and 2002 of legislation designed to increase the level of companies' investment in research and development. ${ }^{1}$ Critical to its success is scientists' as well as accountants', awareness of its existence. ${ }^{2}$ In this case, HMRC are in the unusual position of promoting compliance aimed at reducing corporation tax revenues, at least in the short term. In addition, a broader understanding of the corporate tax knowledge market could influence compliance enforcement policy; i.e. how HMRC might mandate tax

\footnotetext{
${ }^{1}$ Initially when introduced in 2000 the credit was only available to Small or Medium enterprises (SMEs). In 2002 the scheme was extended to cover all other companies or Large companies. At current rates the credit is equal to a corporate tax deduction equal to $175 \%$ or $130 \%$ of qualifying expenditure on R\&D for SMEs and Large companies respectively. Initial difficulties occurred in obtaining agreement of what constituted qualifying $R \& D$ expenditure. The lack of consistency between tax offices led updated guidance being given to HMRC Inspectors (HMT, 2005).

${ }^{2}$ HMRC commissioned in-depth customer research to monitor companies' awareness of the scheme (HMT, 2005).
} 
reporting, or work with (or possibly even regulate) tax agents - a topic currently under review in the U.K. (HMRC, 2009).

The paper is structured as follows. In the next section, we describe the broad relations between HMRC, accounting firms and corporate taxpayers in the context of knowledge markets and review processes of knowledge sharing, followed by a discussion of potential barriers to and facilitators of such processes. Sections three and four respectively outline our method and discussion of our empirical results. Finally, we offer some concluding remarks.

\section{Knowledge and Corporate Tax}

\subsection{Knowledge Markets and Taxation}

In practice, the context of corporate taxation is complex, technical and involves social-legal relationships between many stakeholders (McBarnet, 2003; Mulligan, 2008; Oats and Tuck, 2008). Although there is a critical literature on knowledge in accounting firms generally (e.g. Empson, 2001; Lowe, 2004; Morris and Empson, 1998), prior work on tax knowledge, however, has largely derived from behavioural psychology and involved experimental settings exploring individual tax professionals' judgements and decisions e.g. search processes (Cloyd, 1997; Cloyd and Spilker, 1999; Gibbins and Jamal, 1993). This now extensive empirical literature (Roberts and Ashton, 2003) attempts to explain individual causal effects, but fails to address aggregate tax system-wide knowledge flows and effects.

In this paper, we place the relationship between the three parties involved in communicating, implementing, and utilising changes in tax legislation - HMRC, accounting firms, and corporate taxpayers - in a simple knowledge management context. Davenport and Prusak (2000, p. 27) suggest that knowledge is an economic asset and in the transaction of this asset, several players are active. These players are described as knowledge buyers, sellers, and brokers, although "an individual can perform all three roles in a single day and 
sometimes plays more than one role simultaneously". Knowledge buyers actively seek knowledge. People who share knowledge with others, in return for (financial) compensation, are defined as knowledge sellers. Finally, knowledge brokers are people who connect buyers and sellers. All three types of players aim to benefit from exchanging knowledge. Possible motivations for sharing knowledge are reciprocity, reputation, and altruism. Davenport and Prusak (2000) define knowledge markets on an organisational level and market players on an individual level. However, we believe that knowledge markets may also operate on an interorganisational level, with organisational instead of individual players. In this respect, the relationships between the three major parties in our study can be perceived as a knowledge market in tax legislation and can be visualised as in Figure 1.

\section{[Insert Figure 1 about here]}

The knowledge market's core linkages and several external influences that impose additional contextual complexities are now outlined. First, HMRC develops and communicates new tax legislation and can be regarded as a knowledge seller. ${ }^{3}$ Corporate taxpayers then seek, either by compulsion (for routine compliance) or volition (for tax planning and avoidance), knowledge about new tax legislation. In this respect, they can be conceived of as knowledge buyers. Finally, accounting firms have a role as knowledge brokers. By definition, they operate as intermediaries between corporate taxpayers (knowledge buyers) and HMRC (knowledge seller), a role that can also be described as 'gate keeping' or 'boundary spanning' (Choo, 1998; OECD, 2008).

Corporate taxpayers may decide to hire the expertise of accounting firms as external advisors when they find that they do not possess sufficient knowledge about HMRC's

\footnotetext{
${ }^{3}$ We appreciate that, formally, it is Parliament that through the process of enactment, creates new U.K. tax legislation, which is knowledge creation. However, in practice, HMRC has a lead role in the development and communication of new legislation.
} 
legislation. The two may be seen as co-producers of knowledge (Sturdy et al. 2009) as tax planning, for example, depends on both a detailed knowledge of tax law and the context in which the law is to be applied (Morris and Empson, 1998). This tax advisory role of accounting firms is of course consistent with prior work on the mediating role of consultancy firms in sharing knowledge. Although empirical research on this topic is relatively scarce (Sturdy, 1997), Hansen et al. (1999, p.106) suggest that "knowledge is the core asset of consultancies". Accounting firms offer their clients intangible assets in the form of knowledge or skills and as Fincham (2002, p. 80) notes "need to claim superior expertise to maintain their value and competitive position".

The tax knowledge market is however distinguishable from the general management knowledge market. Participation of knowledge buyers is compulsory with significant penalties for error. These are in addition to general, potential costs of error in terms of reduced profit, market value and reputation associated with consultancy in general. This compulsory nature increases the influence and power of the knowledge broker by reducing the timing option involved in the decision to acquire knowledge. This aspect, compulsion, can induce demand for insurance through the use of a knowledge broker, a service in addition to the value of tax knowledge. This insurance role is distinct from the characterisation of consultants as either innovators or legitimisers (Sturdy et al. 2009). Although we argue our setting is non-competitive, where internal advisers have the ability to refer, or at least influence the decision on referring work to outside advisers, this can counter Fincham's (2002) finding that external advisers are usually reluctant to interact with internal experts in their field. The specialist nature of tax knowledge gives the internal tax expert more power than general management experts. A further distinguishing feature can arise when a potential knowledge broker also acts as the knowledge buyers' independent financial auditor. By using the knowledge broker the corporate tax payer may hope to reduce the probability of the 
auditor subsequently objecting to the proposed financial accounting treatment of a particular tax transaction in which the knowledge broker has been involved (Maydew and Shackelford, 2007). ${ }^{4}$

\subsection{Knowledge Sharing}

The functioning of the UK tax system relies heavily on effective knowledge sharing. Processes of inter-organisational knowledge sharing are unmistakeably connected to intraorganisational processes of knowledge sharing. As Nonaka and Takeuchi (1995, p. 72) state "organizational knowledge creation is a spiral process, starting at the individual level and moving up through expanding communities of interaction, that crosses sectional, departmental, divisional, and organizational boundaries". These authors refer to knowledge creation instead of knowledge sharing because knowledge cannot be objectively shared. Exchanging knowledge implies that people both contribute and collect (e.g., Grant, 1996; Van der Rijt, 2007). Contributing parties try to convey their personal knowledge to others. However, for receivers this knowledge is just impersonal material that needs to be interpreted before it acquires meaning. The knowledge that results from this interpretation process has unique personal features, and is therefore never completely identical to the knowledge of the contributing party (e.g., Conner and Prahalad, 1996). In other words, knowledge is initially created through interpersonal interaction and processes of personal interpretation.

However, knowledge may also develop on other levels than the individual level, for example when it is shared in a group. Likewise, knowledge can be shared within and between organisational and inter-organisational levels. On each of these levels, processes of interpretation take place. This entails an extra challenge for knowledge brokers, such as the

\footnotetext{
${ }^{4}$ A counter argument can be made that corporate taxpayers may avoid using such a broker in order to reduce the auditor's awareness of a particular tax transaction. In the subsequent empirical analysis neither potential influence was identified by interviewees as a consideration in their decisions within the tax knowledge market.
} 
accounting firms in our study, who need to "understand the coding schemes used on both sides of the perimeter, enabling them to recognize significant information on one side and disseminate it on the other side" (Choo, 1998, p. 145).

In corporate taxation, the knowledge that is shared on the inter-organisational level might be expected to have a relatively explicit nature which Morris and Empson (1998) refer to as 'codified knowledge'. However, the interpretation and application of knowledge to different situations is likely to dilute this explicit nature. Thus, the intra-organisational processes in which new tax legislation is interpreted and incorporated by organisations are expected to be less straightforward and are likely to add certain tacitness to the knowledge. Accounting firms and corporate taxpayers give meaning to HMRC's new (explicit) tax legislation. By combining this new information with existing knowledge, they may develop new ideas and find yet unexplored opportunities in applying the new legislation. Again, this is particularly relevant for accounting firms, when considering their role as knowledge brokers. Even though HMRC provides accounting firms equal opportunities to acquire similar knowledge, these firms can distinguish themselves from and gain competitive advantage over other accounting firms by creating new knowledge. The next section focuses on barriers to and facilitators of processes of knowledge sharing.

\subsection{Barriers and Facilitators}

In prior work that focused on the changing role of accountants and their expertise in the Large Business Service of HMRC, Oats and Tuck (2008, p. 40) utilise the concept of communities of practice to explore changing relationships. They note that this concept stems from learning theory where actual learning takes place within a particular social context. They find that the recruitment of accountants by HMRC resulted in improved knowledge of accounting standards and practices within the organisation as a whole, but that barriers exist 
to sharing knowledge between the accounting experts as well as between accounting and tax experts, such as physical isolation and the lack of appropriate technological support. Our research can be distinguished from Oats and Tuck (2008) whose primary focus was on individuals within one unit of HMRC. This study is broader, with a focus on general, though not necessarily formal, knowledge management systems spanning U.K. corporate taxation.

In the knowledge management literature, many factors have been identified that either positively or negatively influence processes of knowledge sharing in and between organisations. From a functionalist perspective, Riege (2005) identifies potential barriers that negatively influence processes of knowledge sharing. These include individual barriers such as lack of time, lack of trust, and demographic differences. Second, he mentions a range of potential organisational barriers, e.g. lack of leadership, an unsupportive culture, and internal competition. Finally, he identifies potential technology barriers, including a lack of technological support and insufficient technological training. In order to understand and potentially improve processes of tax knowledge sharing, it is important to know the barriers to and facilitators of such processes. In their large accounting firm case study, Morris and Empson (1998) describe an internal tax 'think tank' of six of the most technically skilled and creative tax partners which, together with another core database, was used to convey high prestige on selected partners and overcome the barrier of reluctance by professionals to share knowledge (due to the competition for internal promotion).

Aside from the two cases in Morris and Empson (1998), Vera-Muñoz et al. (2006) examine knowledge sharing in audit firms. They suggest information technology systems can facilitate such processes, given that employees are able to work with the available systems. Further, they point out personal interactions within audit teams as facilitators and barriers. Factors that play a role in this respect are organisational culture, procedural justice (fairness of decision processes) and trust, role conflict and role ambiguity, supervision and feedback, 
and a match between organisational culture and individual characteristics. Finally, they focus on the role of intrinsic and extrinsic reward systems in enhancing knowledge sharing.

\subsection{Research Aims}

Because of the differing objectives between tax agencies and corporate taxpayers (e.g. the desired levels of tax) and current tensions between service and enforcement, together with the mediating role of accounting firms, this study aims to provide exploratory evidence on the functioning of the knowledge market in corporate taxation. Based on prior literature, we seek to identify barriers and facilitators and to examine both inter- and intra-organisational processes of knowledge sharing about new tax legislation.

\section{Method}

As this is an exploratory study that is part of a wider project funded by the ACCA, we used a qualitative research method with 19 in-depth interviews conducted with employees from HMRC, accounting firms, and corporate taxpayers throughout the UK. These interviews were designed to yield an initial orientation on processes of knowledge sharing about tax legislation. While interviews provide data that may not be generalised to a wider population, they can raise issues that can be investigated in more depth through a subsequent case or survey method (Horton et al. 2007).

Of the 19 interviews undertaken, three were conducted with HMRC employees - one was involved with "general guidance", two were involved in providing guidance on a specific corporate tax area. We used the "Top 50 accountancy firms", published by Accountancy Age, to select four firms (and seven interviewees) for participation in the study. These included three interviewees from the "big four", two with mid-tier firms. In addition we obtained access to a single office partnership and a sole proprietor. Of the seven interviewees, two 
worked in the area of "formal" knowledge management systems while the remaining five were involved with practical aspects of corporate tax. All interviewees held senior positions within their respective firms.

To obtain a reasonable coverage of likely issues faced by corporate taxpayers, we identified several key factors and screening requirements prior to selection for interview. Factors that were used in selecting potential firms to interview were the degree of regulation, the degree of capital intensity, increases in $R \& D$ expenditure ${ }^{5}$, making a tax loss, firm size, foreign presence, and partnership status. Also, in securing a minimum level of regulatory responsibility, firms were required to be quoted. Firms were identified in the following industries: manufacturing; wholesale, retail, trade; transport and communication; government; and electricity, gas, water. Datastream and FAME databases were used to select organisations for participation in the project by reference to the characteristics identified above. The organisations were contacted by telephone and email. Ultimately, nine organisations in several industries agreed to participate. The interviewees in these organisations were all employed at senior levels in the field of taxation and/or knowledge management. Of the 19 interviews, eleven interviews were conducted face-to-face, and eight interviews were conducted by telephone. ${ }^{6}$ Most face-to-face interviews were conducted by two interviewers, the telephone interviews by one interviewer.

Three different interview guides were designed for conducting the interviews: one for HMRC, one for the accounting firms, and one for the corporate taxpayers. They covered similar questions but were modified to suit the precise interviewee (the interview guide for accounting firms is reproduced in the Appendix). An interview guide is different from an

\footnotetext{
${ }^{5}$ We used R\&D as a selection filter due to the new (at the time) R\&D tax credit that required knowledge (scientific) from disciplines other than tax accounting, involved a relief by way of tax credit, rather than charge on profit, and because it was new legislation that was designed to incentivise a certain behaviour (i.e. increase R\&D expenditure).

${ }^{6}$ The telephone interviews were because of travel and time constraints. However, the same interview guides were used as for the face to face interviews.
} 
interview questionnaire in the sense that there is no strict order in the questions that are asked by the interviewers (Horton et al. 2007). In addition, the precise formulation of questions can vary per interview. Interviews conducted with an interview guide have a relatively open character and the course of the interview is largely determined by the information that is provided by the interviewee. The guide lists several topics and focal points that enable the interviewers to steer the interview. In the interview guides that were used in the present study, a variety of subjects were covered, among which communication flows about new tax legislation between HMRC, accounting firms and corporate taxpayers, communication flows about new tax legislation within HMRC, accounting firms, and corporate taxpayers' firms, and barriers to and facilitators of sharing knowledge within and between organisations. All interviews were recorded and transcribed by one of the authors (Hayes and Mattimoe 2007). Subsequently, the transcripts were coded and analysed using NVivo software (AndersonGough, 2007).

\section{Results and Discussion}

The purpose of this paper is to empirically investigate the knowledge sharing relationships in the corporate tax knowledge market (schematically shown in Figure 1). In addition, we wish to link our empirical findings into current literature on tax administration as well as the changing corporate tax environment. We first discuss the knowledge flows between HMRC and the corporate taxpayer (Section 4.1), followed by our findings with respect to accounting firms (Section 4.2). We then outline our findings on intra-organisational processes of tax knowledge sharing (Section 4.3).

Prior to outlining our results, we acknowledge the existence of international differences arising from national context and culture that impact on firms' strategic management as well as different regulatory styles (Sakurai, 2002). In the tax context of 
transfer pricing, Sakurai (2002) has documented the existence of such differences, but also notes they are becoming less marked, due to a harmonization of management styles.

\subsection{Knowledge Flows: HMRC $\Leftrightarrow$ Corporate Taxpayers}

When focusing on the inter-organisational knowledge flows between HMRC and corporate taxpayers in the tax legislation knowledge market, the HMRC interviewees indicated that HMRC actively contacts and advises both experienced and inexperienced corporate taxpayers. They provide written information to corporate taxpayers (e.g., notes, guidance, articles, publications, internet) that in some cases is customised to the tax expertise of the corporate taxpayer, such as manuals for people with a high tax expertise, tax bulletins for people with a moderate tax expertise, and press releases for people with little tax expertise. The corporate taxpayer interviewees mentioned that they particularly use the HMRC manuals and website because these accurately reflect HMRC's argumentation and interpretation. HMRC also provides information through seminars, training events, assessments, and visits on demand. Moreover, HMRC and corporate taxpayers co-operate, for instance in the development of guidance and schemes. This ensures HMRC that the (impact of) their tax guidance is clear and understood. HMRC is also motivated to share knowledge with corporate taxpayers because they believe that this will improve the standard of compliance consistency, and certainty, and will ultimately encourage innovation and competition in the marketplace.

Corporate taxpayer interviewees described HMRC as understanding, flexible, and pragmatic. They lobby by participating in representative bodies, membership of consultation bodies, business forums, accounting firms, and also directly contact HMRC for discussion and the exchange of ideas. The interviewees believe that HMRC values their feedback. In addition, some of the interviewees mentioned that there is a fair exchange of knowledge 
between their organisation and HMRC. In other words, they feel they contribute as much knowledge as they receive or collect. These factors may encourage them to share knowledge with HMRC and support the two-way flows depicted in Figure 1.

Thus on the one hand, there is evidence of a co-operative arrangement where clearly the enabling work of HMRC over the last few years has improved corporate perceptions about HMRC and its customer service (Braithwaite, 2007). These initiatives followed a 2001 Review of Links with Business, and now there are several HMRC fora (e.g. Business Tax Forum, Large Business Forum etc.) that facilitate direct knowledge sharing.

Besides these motives to share knowledge, both the HMRC and corporate taxpayer interviewees identified several similar barriers to knowledge flows. The success of a corporate taxpayer's claim or specific position can be dependent on non-tax professionals in the corporate taxpayer's organisation. For example, in examining a corporate taxpayer's R\&D tax credit claim, HMRC needs information from researchers in the organisation. They should be able to convince HMRC of the relevance of such a claim for the organisation. However, HMRC sometimes experienced difficulty in identifying non-tax professionals in organisations. And those that were identified often did not prioritise working on a claim. Another barrier that HMRC perceived is anxiety on the corporate taxpayer's side. The interviewees indicated that corporate taxpayers are hesitant to stand out and express opinions because they fear that this will invite an enquiry or tax bill. This barrier was also recognised by corporate taxpayers. Corporate taxpayers may take into account legal considerations, (i.e. whether the opinion is covered by legal professional privilege ${ }^{7}$ ), that influence the form in which knowledge is retained and even influence whether it is created in the first instance. Companies may keep such knowledge "close to their chest", and legal professional privilege

\footnotetext{
${ }^{7}$ Legal professional privilege is a common law principle in England and Wales that confers a right on clients for client-lawyer communications to be treated as confidential communications; (i.e. any documents are not subject to HMRC's powers of inspection).
} 
may influence the decision on whether to hire a specialist law firm as an adviser or an accounting firm.

"Most companies have no problem at all in making factual information available to revenue authorities. I think where companies start to have a problem is on expressions of opinion, either internally or prepared by advisors. ... if we go out for advice, much of that expression of opinion is not privileged unless it's within very confined sort of parameters involving lawyers. And therefore there's a lot of concern about whether we even inadvertently will find ourselves in a position of having to provide expressions of opinion to revenue authorities when it's not really appropriate" (corporate taxpayer interviewee 1).

A further important barrier in sharing knowledge recognised by corporate taxpayer employees was a limited ability to share knowledge due to several reasons, such as a lack of knowledge management skills, a shortage of time to share knowledge, and information overload.

In addition, the tax landscape has changed in the last several years (Hasseldine, 2008). Structural changes in HMRC since its formation in 2005 have involved a significant decline in staff numbers and the closure of local offices leading to less local knowledge and contacts on both sides and more formal relationships.

\subsection{The Role of Accounting Firms}

Our interviews indicate that the intermediary role of accounting firms is acknowledged by all players on the knowledge market. Both HMRC as knowledge seller and corporate taxpayers as knowledge buyers perceive accounting firms as knowledge brokers. Accounting firms, unsurprisingly, vigorously defend this role.

"HMRC are trying to be very close to the taxpayer and almost be seen as business advisors and we clearly want to stand in the middle of that. So we don't necessarily want HMRC to be going straight to corporates because we believe our role is to facilitate that. ... we have a lot more experience actually as to how we can make that work effectively. Whereas sometimes the corporates can be quite naïve and see HMRC as their friend, where actually they're never going to be that. And they can't 
be because they're a Governmental institution and actually they've got their rules to abide by" (accounting firm interviewee 1).

HMRC interviewees demonstrated a relatively positive attitude towards the mediating role of accounting firms in communicating with corporate taxpayers, although there is concern about what might be termed "rogue" agents (HMRC, 2009). ${ }^{8}$ HMRC use knowledge brokers such as accounting firms to distribute knowledge amongst their (potential) clients. Accounting firms are in the paradoxical position of presenting for example, consultation activities over proposed tax legislation as being in the public interest, (e.g. PricewaterhouseCoopers, 2006), while simultaneously promoting the benefits to their clients from their specialist knowledge. Whilst involvement of accounting firms at the consultative stage of draft legislation can potentially improve the quality of the legislation in administrative terms, their involvement increases the firms' legitimacy both in the eyes of society at large and their clients. Accounting firms are often the initial contact for HMRC with corporate taxpayers. The interviewees found this mediated communication more efficient than communicating with individual corporate taxpayers, as accounting firms publicise HMRC's schemes (such as the R\&D scheme) and encourage corporate taxpayers to apply. As one of the interviewees explained:

"If we're doing an enquiry and we find the agent's got the wrong end of the stick, if you can educate the agent and get them to do things right in the future, that has a huge effect compared with just educating one company" (HMRC interviewee 2 ).

Knowledge flows between HMRC and accounting firms can be perceived as an interactive communication process. According to the interviewees, HMRC invites accounting firms to

\footnotetext{
${ }^{8}$ It should be noted that there is no regulation or registration required of tax agents in the UK (other than filling in a form). This is in contrast to countries such as Australia and the U.S. where preparers of tax returns are licenced to practice.
} 
provide feedback and participate in consultative committees. ${ }^{9}$ The interviews that were conducted with employees from accounting firms indicate that they do provide information to HMRC, for example when they perceive a major impact of legislation on clients or on the economy in general. They also regularly enquire about HMRC's views on tax issues. The interviews show that accounting firms generally have a positive opinion about HMRC due to their high quality manuals, their pro-activity (in making visits, sending mails, and publishing), and their flexibility and helpfulness.

Not only HMRC, but corporate taxpayer interviewees mentioned benefits from having accounting firms as intermediaries in knowledge flows from and to HMRC also, as demonstrated by the following quotes:

"HMRC tell it as it is, the accounting firms analyse it and explain the implications for you, which is quite helpful" (corporate taxpayer interviewee 3).

"Another way we might feed things back is via the accounting firms, so they might write to us and say 'Do you have any views that you'd like us to put in our representations?' And we find that quite a convenient way to do things" (corporate taxpayer interviewee 3 ).

The corporate taxpayer interviewees said that they do regularly rely on accounting firms, not only for communicating with HMRC but also to assure they have a correct interpretation of tax legislation (so for risk minimisation checks), to acquire alternative interpretations and views, for brainstorming, to get second opinions, to check for new knowledge on tax legislation, and when they possess insufficient tax skills, tax knowledge, and tax resources. In addition, the interviewees mentioned that they regularly receive free emails with tax headlines from accounting firms. According to one of the accounting firm interviewees, accounting firms share such (free) knowledge to raise the corporate taxpayers' interest, while

\footnotetext{
${ }^{9}$ One specific example is the HMRC Agent and Advisers Strategy Steering Group formed in July 2006.
} 
at the same time making sure not to give away trade secrets (e.g. Morris and Empson, 1998, p.615). The interviews indicate that most corporate taxpayers hire accounting firms for specific, complex tasks. They believe that in those situations, the advantages of hiring accounting firms outweigh the (potential) disadvantages. In this respect, strong relationships are considered to be very important.

"If we feel we can't rely solely on our own efforts, then we'll go to a professional firm. Which for most issues, probably will be a big four accounting firm and ask for their formal advice. If it's a very specific legal issue, we might go to a law firm" (corporate taxpayer interviewee 1).

Accounting firms are also hired from a corporate (or personal) risk management point of view, as documented by Mulligan and Oats (2009) and explained by this interviewee:

"You want some external assurance that the decision you've come to is the right one. $\ldots$ in the sense that you want someone else to have come to the same conclusion as you, so that you don't get sacked for it later" (corporate taxpayer interviewee 3).

Interviews with accounting firms confirmed that they consider strong relationships with corporate taxpayers essential too. The interviewees expressed their awareness of the need to offer corporate taxpayers added value, since tax information is publicly available.

"We use them but we're not fully reliant on them. We listen to them, take their advice and then implement it. We don't say to tax advisors, 'come in and do the whole lot'. But we just listen to what they've got to say but a lot of the stuff we do ourselves" (corporate taxpayer interviewee 7).

This added value, the interviewees indicated, exists in their ability to demonstrate expertise and experience; to provide advice, process knowledge, and interpretation; to be pro-active and innovative; to develop and apply intellectual property; to focus on the specific context of the corporate taxpayer, and to create strong relationships. Accordingly, accounting firms can be seen to provide an important "enforcer" role themselves - in the dissemination of 
knowledge to taxpayers and enforcement of compliance with unambiguous legislation (Hite and Hasseldine, 2003).

Nonetheless, the interviews do show that knowledge sellers and buyers also experience hesitations towards the role of knowledge brokers. Especially the commercialisation of knowledge by accounting firms was criticised. ${ }^{10} \mathrm{HMRC}$ interviewees expressed worries about the possibility of accounting firms having a different interpretation of tax legislation. For instance, HMRC (2009) is concerned not only about tax agents who submit a high volume of repayment claims by advertising a service that claims to secure repayments from previous years' tax liabilities, but also by mass marketed, or off the shelf, tax avoidance schemes. This is despite the introduction of the Disclosure of Tax Avoidance regime in the U.K., and the perceived prevalence of 'unacceptable' avoidance has led to recent ministerial comment on the topic. ${ }^{11}$ In essence, accounting firms are not only enforcers, but also exploiters (Hasseldine et al. 2003).

Corporate taxpayers also appeared to experience doubts about the reliability of accounting firms, especially with respect to the way accounting firms create knowledge.

"They come and review our files, have a chat to see what we are doing. ... often I say to myself, they probably learn more from us than we learn from them when they come to our organisation, sit down and discuss and see what we do. And I'm sure there are things which they can then go and sell to other companies. I'm sure it happens. ... yes, I think the professional folks do come in and see how we are doing things and I'm sure they take that away and see that as an opportunity to go in other firms and do a similar exercise" (corporate taxpayer interviewee 8).

"The accounting firms and law firms are extremely sensitive to the commercial value of knowledge and information. To put it very cynically, they need to appear to be the fountain of all knowledge and wisdom, while actually imparting as little as possible, so they preserve it for selling to you on a future occasion" (corporate taxpayer interviewee 1).

\footnotetext{
${ }^{10}$ This finding may have been influenced by the fact that our interviews took place subsequent to KPMG being fined \$66million in the U.S. for marketing abusive tax shelters.

${ }^{11}$ Speech by Hon. Stephen Timms, Financial Secretary to the Treasury at an International Conference on Tax Analysis, London, 21 September 2009.
} 
Corporate taxpayers thus fear an inequality in the amount of knowledge that accounting firms acquire from and contribute to their organisations. The reliability of accounting firms is further questioned, though as accounting firms have the tendency to emphasise risks, which obligates corporate taxpayers to invest in minimising these risks.

"We had one of the big five in to do us [an employment-related tax compliance] review, just to make sure everything was working alright. And the next you know you get a 20-page report, a sort of scathing report saying 'this is potentially wrong, this is potentially wrong, this could be troublesome, this could cost us a lot of money'. And once such a report is written, the hands of the management are tied, they have then got to act on it" (corporate taxpayer interviewee 8).

Although the evidence suggests the market is generally cooperative this may be a specific area where the characteristic is at its weakest. When external advisers are employed on an ad hoc basis or an additional assignment is being considered, existing internal advisers through their specialist tax knowledge have the power to influence the basis on which external advisers are consulted. In effect, external advisers have to be credible in the eyes of internal tax specialists and non-tax specialists. This may counter the general tendency of external advisers to shun dealings with internal parties (Fincham, 2002).

Aside from quality and reliance issues, the choice of supplier can be influenced by the ability to retain or capture the knowledge created. There are potential limitations to the retention of both internally and externally generated knowledge.

“... people sometimes say there's a benefit in undertaking research in-house because you retain the knowledge but I question that ....given realistic turnover and movement of people within a tax department, you probably don't really preserve it in perpetuity anyway" (corporate taxpayer interviewee 1 ).

"I think the client is always wondering whether they've actually captured the knowledge, which has been so expensively purchased. ... we still feel compelled to 
go out and take expert advice ... even if we think we understand the issues, we still have to do that to confirm that we've not forgotten anything that's happened in the law in the meantime" (corporate taxpayer interviewee 1).

The interviews that were conducted with employees from accounting firms indicate that accounting firms are aware of (the view of the other players in the knowledge market on) their precarious role as knowledge broker. The interviewees of accounting firms did not express any significant barriers to knowledge flows with HMRC. The barriers that they pointed out with respect to sharing knowledge with corporate taxpayers, however, showed similarities to those mentioned by HMRC.

A barrier that was recognised by interviewees of accounting firms, and HMRC as discussed previously, is anxiety experienced by the corporate taxpayer. This anxiety consists of concerns that activities of accounting firms will attract HMRC for investigations, and sensitivity about confidentiality issues (such as sensitive information that the corporate taxpayer does not want to be shared). Consequently, accounting firms are eager to enhance perceived reliability among and maintain strong relationships with HMRC and corporate taxpayers.

"We really don't use information from one client with another, it's too risky. And you know, we'd need permission and on the whole, we don't want to go to clients and ask their permission for that sort of thing, so we just don't do it. We change teams, so that we don't have people working on competitor [R\&D] claims either. So it's not that you might have one person with that knowledge going from one claim to the next, we tend to split our teams in such a way that within a sector, we don't have people working on direct competitor's claims" (accounting firm interviewee 3 ).

"The firm as a whole is very, very clear on its terms of disclosure and filing positions and you know, ... not only do we wish to be whiter than white, we wish to be seen to be whiter than white" (accounting firm interviewee 1).

\subsection{Intra-organisational Knowledge Flows}


This section considers barriers and facilitators of intra-organisational knowledge sharing and our findings are summarised in Table 1. HMRC attempts to give its inspectors insight in the issues and perspectives of corporate taxpayers, in order to understand their fears and concerns. Moreover, HMRC aims to establish consistency among its units through submissions in precedence files, meetings, and discussions. Further, processes of intraorganisational knowledge sharing take place by means of electronic discussion groups, email, intranet, telephone, and technical manuals. Some of the barriers to intra-organisational knowledge sharing that interviewees identified are information overload and inadequate IT systems (NAO, 2007; Cabinet Office, 2007).

The findings show that most corporate taxpayers try to handle the majority of tax issues internally. They share tax knowledge personally and electronically, for instance via meetings, conference calls, emails, intranet, and databases. Some examples of facilitators of intra-organisational knowledge flows that were mentioned by interviewees are good communication skills, training, holding onto staff, investing in IT systems to facilitate knowledge sharing, arranging formal appointments, and management support. Corporate taxpayer interviewees also indicated using external sources for acquiring and developing internal tax knowledge.

The successful transfer of knowledge can be improved by the appropriate motivation and use of subject experts, both internally and externally. For instance, as Mulligan and Oats (2009) also document, an external knowledge seller such as HMRC can be utilised to demonstrate the significance and benefits of tax work, and add credibility to a particular transfer.

“One thing we do and we've always been very keen to do is use visits from HMRC to come in and actually take them out to departments to make departments realise that it is a real issue. And it puts the departments on edge, which probably isn't a good thing but it makes them realise that tax is serious. ... we are quite keen to make sure that 
HMRC are visible on visits that we take them round" (corporate taxpayer interviewee 7).

Reducing barriers is considered to be important, since the interviews indicate that intra-organisational knowledge flows are essential for successful inter-organisational flows of knowledge and vice versa. Only with the appropriate knowledge, companies are able to utilise this knowledge to their benefit. In this respect, several interviewees mentioned that their company is often reliant on non-tax professionals such as business accountants and HR experts in making successful tax claims. Consequently, internal knowledge buyers and sellers can be identified (Oats and Tuck, 2008).

\begin{abstract}
"Sharing with[in] the businesses is obviously one of the tricky things that I have to deal with because ... I am actually reliant on accountants of the businesses who aren't actually tax people, to do a lot of the basic tax work. ... it is helpful if they have some tax knowledge. But on the other hand, you don't want to so overburden them with tax knowledge that either they can't cope or frankly it's something that they only do once a year and ... you can't expect them to sort of give their all to it if they're not going to use it again for a year" (corporate taxpayer interviewee 2).
\end{abstract}

The dynamic relationship and interdependence between inter- and intra-organisational knowledge flows can also be found in the interviews that were conducted with employees of accounting firms. An important issue mentioned here focuses on detail and concerns over information overload.

\footnotetext{
"The chances are that clients have seen whatever it is we've seen and we need to be able to have a conversation with the clients about the implication. And there are varying degrees, in terms of being able to get knowledge out to our people, so they should always be aware of what's out in the public domain ... They need to know enough to then have a sensible conversation. They might not need to know the detail or the answers, they just need to be aware of maybe some of the implications. And then within a very short space of time, we actually need to have taken it to the next stage and actually be looking at the interpretation and the full implications, what some of the solutions and answers might be to that. And it's trying to get different levels of knowledge out at the right time. And as a technical group, we've got some of the best technical brains sat within the group and we can be very, very detailed. So one of our
} 
challenges frequently, is almost like 'do they really need the Rolls Royce or would the pushbike do at the moment?"' (accounting firm interviewee 1).

In other words, accounting firms should be able to respond to external developments quickly in order to correctly advise their clients and maintain credibility. So the development of new tax legislation by HMRC has an impact on the intra-organisational knowledge flows of accounting firms, and consequently on their inter-organisational knowledge flows with corporate taxpayers. In order to reduce the risk of overloading their employees with information, accounting firms use different communication methods suitable for disseminating different levels of knowledge. These levels, as one of the interviewees distinguished, are awareness (communicated through headlines), working knowledge (produced by giving examples), and deep expertise (created by training).

Accounting firms are inherently focused on acquiring and maintaining knowledge and the interviewees mentioned that they experience a lot of freedom for creativity, innovativeness, and exploring ideas. Knowledge within accounting firms is shared and created through the intranet, email, newsflashes, networks and communities, training, and self-learning. Further, the interviewees indicated that a common method of acquiring and using knowledge is the precedence based system which typically relies on voluntary submissions. These submissions are filtered from client information before being shared internally.

\footnotetext{
"Very typically for our tax users, it's precedent based information; what have we done, what advice has been given to other clients, that kind of stuff. Our tax practice relies heavily on end user submissions. So people in the tax practice submit content they've generated through the course of their work. That content is then processed and it's filtered, it's sanitised, by which we mean client names are stripped out.....[O]ur tax practitioners can go and search over all of the internal [practice name] generated content. But if for example, they want to access legislation at the moment, they need to ... go and access for example, the LexisNexis Butterworths site over the [practice name] firewall. So effectively, if you're looking for [practice name] precedence, and legislation, you've got to ... run two searches" (accounting firm interviewee 2).
} 
In the above setting the accounting firm is acting in all three capacities, as (internal) knowledge buyer, seller and broker. The effectiveness of a precedent system is dependent on the volume and quality of the submissions, the generation of which can conflict with more immediate demands.

“.... people are all being measured nowadays in this environment, they're all being measured on utilisation, charge-out rates and that kind of stuff. ... creating knowledge submissions; they can't charge that to anything, so it really has to be done ... almost out of the goodness of their hearts." (accounting firm interviewee 2).

As previously discussed Morris and Empson (1998) observe that staff may be reluctant to share knowledge internally with colleagues who may be considered as competitors in the internal market for promotion. Conversely, the same influence could encourage sharing as a way of demonstrating prowess in tax and lead to informal "upward hierarchical" sharing to supplement the more anonymous, or less visible, formal sharing systems. The efficacy of accounting firms' attempts to capture knowledge could therefore be dependent on individuals' motivation as well as their capacity to contribute.

\section{Concluding remarks}

This study extends prior critical accounting research (Cooper and Robson, 2006; Empson, 2001; Gibbins and Jamal, 1993; Morris and Empson, 1998; Sikka, 2008) by establishing a baseline of findings in respect of the management of tax knowledge within and between accounting firms, companies and tax agencies. Understanding the facilitators and barriers to tax knowledge creation and sharing offers a new contextual perspective over and above a more generic discussion of the commercialization, professionalization and regulation of accounting. Our concluding remarks outline our direct knowledge market findings while 
interspersing implications for the changing institution of taxation and implications for future critical literature in this area.

Accounting firms experience considerable challenges in the knowledge market. As distinct from general management consultants they possess what can be termed 'strong knowledge', i.e. knowledge associated with codified or theoretical forms (Morris and Empson, 1998). However, like general consultants, they also possess sector context knowledge which falls between the extremes of 'strong' and 'weak' knowledge (Fincham et al. 2008). Accounting firms try to establish and sustain a strong intermediary position between HMRC and corporate taxpayers. Accordingly, HMRC regards accounting firms as an important link in the chain of sharing knowledge about tax legislation with corporate taxpayers. They value having a good relationship and are willing to share knowledge with each other. However it is clear that accounting firms play conflicting enforcer and exploiter roles. From an HMRC perspective, tax accountants are analogous to a bee; they provide a useful knowledge transfer function (pollination) but simultaneously facilitate higher levels of tax planning (the sting!).

Exactly how tax agencies and policy-makers should respond to this "double-edged sword" is unclear. We believe there is a tension between the positive 'enforcing' role played by accounting firms which might be regarded as the "oil in the tax system engine" and which may imply friendly customer service for agents and less regulation of accountants. In contrast, there is concern over the 'exploiter' role played by accounting firms (e.g. Sikka, 2008; 2010) where they facilitate the reduction of corporate tax bills through the use of sophisticated planning and avoidance techniques. Our results show that HMRC are aware of the simultaneous benefits and disadvantages they accrue from working with agents. More recently, HMRC has stated that, although it is not calling for compulsory registration of tax 
advisers/agents, proposals contained in "Working with tax agents" (2009) would give it greater powers in controlling agents.

Similarly our results suggest that corporate taxpayers themselves clearly perceive this dual role played by accounting firms. They acknowledge and accept the role of accounting firms as knowledge brokers, but meanwhile they are highly aware of potential risks involved. There are two important barriers to sharing knowledge with accounting firms. First, on reliability issues, corporate taxpayers sometimes experience an inequality in the knowledge flows from and to accounting firms. They have the feeling that they benefit less from their relationship with accounting firms than accounting firms do (e.g., Fincham, 2002; Sarvary, 1999). Second, in terms of scaremongering, corporate taxpayers feel that accounting firms have the tendency to exaggerate risks in order to validate and secure future assignments. Future research might examine the balance between the commercial orientation of accounting firms and healthy professional scepticism over the tax enforcement risks faced by their clients.

Intra-organisational processes of knowledge sharing and creating in accounting firms are largely dependent on the knowledge that is acquired externally (from HMRC and corporate taxpayers). Subsequently, accounting firms share the knowledge that is created internally with HMRC and corporate taxpayers. Corporate taxpayers use external sources such as HMRC to add credibility to taxation and stimulate intra-organisational processes of sharing tax knowledge. In sum, sharing knowledge between organisations contributes to the development of knowledge in organisations, and sharing knowledge in organisations has consequences for inter-organisational knowledge flows. Therefore it is important to reduce not only barriers to inter-organisational knowledge flows, but to intra-organisational knowledge flows as well. Corporate taxpayers realise that there is a risk to sharing knowledge with HMRC because they perceive it could lead to negative tax consequences. This in turn 
creates an intra organisational barrier within corporates as there is a fear that the revenue authority might see tax-sensitive documents which the corporate would rather they did not. Hence, revenue authorities may respond with increased reporting requirements (e.g. the UK Disclosure of Tax Avoidance Schemes legislation). While such regimes may be useful for the revenue authority, they also impose additional complexity and compliance costs on corporate taxpayers and further consulting opportunities for accounting firms and, arguably, run counter to the spirit of trust and co-operation, espoused by Braithwaite $(2003 ; 2007)$ and Kirchler et al. (2008).

One of the barriers to intra-organisational knowledge flows, recognised by HMRC, accounting firms, and corporate taxpayers, is information overload. This might be expected in a globalised world of extremely complex tax systems. Of course, this is consistent with our enforcer/exploiter findings for accounting firms. Such high complexity levels create opportunities for knowledge brokers, and indeed the tax system wouldn't function without the services of accounting firms (HMRC, 2009).

In conclusion, this study contributes to prior critical accounting literature by exploring processes of knowledge sharing between a revenue authority, accounting firms, and corporate taxpayers, and the implementation and utilisation of tax knowledge within each of these organisations. Overall, our findings suggest that the extant features of the tax knowledge market revealed in this study do create an unavoidable tension between customer-friendly initiatives - based on the promotion of trust and co-operation in tax administration, and initiatives targeted at corporates by those who believe that corporate taxpayers are not paying sufficient taxation (for whatever reason) and must be encouraged, incentivised or enforced to pay more. Our prognosis is that this tension will continue to reinforce and maintain the complex nature of the market for corporate tax knowledge. 


\section{References}

Anderson-Gough, F. Using computer assisted qualitative data analysis software: Respecting voices within data management and analysis. In C. Humphrey and B. Lee (eds) The Real Life Guide to Accounting Research: A behind the scenes view of using qualitative research methods, pp. 373-390. Oxford: CIMA Publishing 2008.

Bonner S, Davis J, Jackson B. Expertise in corporate tax planning: The issue identification stage. Journal of Accounting Research 1992; 30(Supplement):1-28.

Braithwaite V (ed). Taxing democracy. Understanding tax avoidance and evasion. Farnham: Ashgate, 2003.

Braithwaite V. Responsive regulation and taxation: Introduction. Law and Policy 2007; 29:310.

Cabinet Office. Capability review of HMRC. London: Cabinet Office, 2007.

Choo CW. The knowing organization: How organizations use information to construct meaning, create knowledge, and make decisions. New York: Oxford University Press; 1998.

Cloyd B. Performance in tax research tasks: The joints effects of knowledge and accountability. The Accounting Review 1997;72(1):111-131.

Cloyd B, Spilker B. The influence of client preferences on tax professionals' search for judicial precedents, subsequent judgments and recommendations. The Accounting Review 1999;74(3):299-322.

Conner KR, Prahalad C. A resource-based theory of the firm: Knowledge versus opportunism. Organization Science 1996; 7(5):477-501.

Cooper DJ, Robson K. Accounting, professions and regulation: Locating the sites of professionalization. Accounting, Organizations and Society 2006;31:415-444. 
Davenport TH, Prusak L. Working knowledge: How organizations manage what they know. Boston: Harvard Business School Press, 2000.

Empson L. Introduction: Knowledge management in professional service firms. Human Relations 2001;54(7):811-817.

Fincham R. The agent's agent: Power, knowledge, and uncertainty in management consultancy. International Studies of Management \& Organization 2002;32(4):67-86.

Fincham R, Clark T, Handley K, Sturdy A. Configuring expert knowledge: The consultant as sector specialist. Journal of Organizational Behavior 2008;29:1145-1160.

Freedman J, Loomer G, Vella J. Corporate tax risk and tax avoidance: new approaches. British Tax Review 2009;(1):74-116.

Gibbins M, Jamal K. Problem-centred research and knowledge-based theory in the professional accounting setting. Accounting, Organizations and Society 1993;18(5):451-466.

Global Forum. Moving forward on the global standards of transparency and exchange of information for tax purposes. (Paris: OECD, 2009).

Grant RM. Toward a knowledge-based theory of the firm. Strategic Management Journal 1996; 17:109-122.

Hansen MT, Nohria N, Tierney T. What's your strategy for managing knowledge? Harvard Business Review 1999;77(2):106-116.

Hasseldine J, Hite P, Al-Khoury A, James S, Toms, S, Toumi M. Tax practitioners and tax compliance. In A. Lymer and D. Salter (eds.) Contemporary Issues in Taxation Research, pp. 17-43. Aldershot: Ashgate, 2003.

Hasseldine J. The search for best practice in tax administration. In C. Evans and M. Walpole (eds.), Tax administration: Safe harbours and new horizons, pp. 7-18. Birmingham: Fiscal Publications, 2008. 
Hayes T, Mattimoe R. To tape or not to tape: Reflections on methods of data collection. In C. Humphrey and B. Lee (eds) The Real Life Guide to Accounting Research: A behind the scenes view of using qualitative research methods, pp. 359-372. Oxford: CIMA Publishing, 2008.

Hite P, Hasseldine J. Tax practitioner credentials and the incidence of IRS audit adjustments. Accounting Horizons, 2003;17(1):1-14.

HM Revenue \& Customs. Working with tax agents: A consultation document. London: HMRC, 2009.

HM Treasury. Supporting growth in innovation: enhancing the R\&D tax credit, London: HMT, 2005.

Horton J, Macve R, Struyven G. Qualitative research: Experiences in using semi-structured interviews. In C. Humphrey and B. Lee (eds) The Real Life Guide to Accounting Research: A behind the scenes view of using qualitative research methods, pp. 339357. Oxford: CIMA Publishing, 2008.

Kirchler E, Hoelzl E, Wahl I. Enforced versus voluntary tax compliance: The "slippery slope" framework. Journal of Economic Psychology 2008;29:210-225.

Lowe A. Postsocial relations: Toward a performative view of accounting knowledge. Accounting, Auditing \& Accountability Journal 2004;17(4):604-628.

Maydew E, Shackelford D. The changing role of auditors in corporate tax planning. In Auerbach A, Hines J, and Slemrod J. (eds), Taxing corporate income in the 21st century. Cambridge: New York : Cambridge University Press, 2007.

McBarnet D. When compliance is not the solution but the problem: from changes in law to changes in attitude. In V. Braithwaite (ed) Taxing democracy, pp. 229-243. Farnham: Ashgate, 2003. 
Morris T, Empson L. Organisation and expertise: An exploration of knowledge bases and the management of accounting and consulting firms. Accounting, Organizations and Society 1998;23(5/6):609-624.

Mulligan E. Tax planning in practice: A field study of U.S. multinational corporations. Unpublished University of Warwick Ph.D dissertation, 2008.

Mulligan E, Oats L. Tax risk management: Evidence from the US. British Tax Review 2009:680-701

National Audit Office. Management of large business Corporation Tax. London: NAO, 2007.

Nonaka I, Takeuchi H. The knowledge-creating company: How Japanese companies create the dynamics of innovation. New York: Oxford University Press, 1995.

Oats L, Salter D. Tell us what you know and we'll tell you if it matters: Disclosure of tax avoidance schemes. Paper presented at the Taxation Research Network Conference, NUI Galway, 2008.

Oats L, Tuck P. Accounting knowledge as a technology of government. Paper presented at the $8^{\text {th }}$ Interdisciplinary Perspectives on Accounting Conference, Cardiff, 2006.

Oats L, Tuck P. The relationship between HM Revenue and Customs and large corporate taxpayers: The changing role of accountants. London: ICAEW, 2008.

OECD. Study into the role of tax intermediaries. Paris: OECD, 2008.

Owens J. Tax and development: Why tax is important for development. Tax Justice Focus 2009;4(4):1-3.

PricewaterhouseCoopers. Pre-Budget Report 2006: A need for further consultation. 2006. www.ukmediacentre.pwc.com/content/detail.aspx?releaseid=2110\&newsareaid=2. Accessed 5 May 2010.

Riege A. Three-dozen knowledge-sharing barriers managers must consider. Journal of Knowledge Management 2005;9(3):18-35. 
Roberts ML, Ashton RH. Using declarative knowledge to improve information search performance. Journal of the American Taxation Association 2003;25(1):21-38.

Sakurai Y. Comparing cross-cultural regulatory styles and processes in dealing with transfer pricing. International Journal of the Sociology of the Law 2002;30:173-199.

Sarvary M. Knowledge management and competition in the consulting industry. California Management Review 1999;41(2):95-107.

Sikka P. Enterprise culture and accountancy firms: New masters of the universe. Accounting, Auditing \& Accountability Journal 2008;21(2):268-295.

Sikka P, Willmott $\mathrm{H}$. The dark side of transfer pricing: Its role in tax avoidance and wealth retentiveness. Critical Perspectives on Accounting 2010;21:342-356.

Sturdy A. The consultancy process: An insecure business. Journal of Management Studies 1997;34(3):389-413.

Sturdy A, Clark T, Fincham R, Handley K. Between innovation and legitimation: Boundaries and knowledge flow in management consultancy. Organization 2009;16(5):627-653.

Toumi M. Cultures of compliance: British and French tax enforcement compared. Unpublished University of Lancaster Ph.D dissertation, 2008.

Tuck P. A study of the changing relationship between large corporates and the Inland Revenue, Unpublished University of Warwick Ph.D dissertation, 2007.

Van der Rijt PGA. Precious knowledge: Virtualness and the willingness to share knowledge in organizational teams. (Amsterdam: Author, 2007).

Vera-Muñoz SC, Ho JL, Chow CW. Enhancing knowledge sharing in public accounting firms. Accounting Horizons 2006;20(2):133-155. 
FIGURE 1

\section{Knowledge market in Tax Legislation}

Core identities in market:

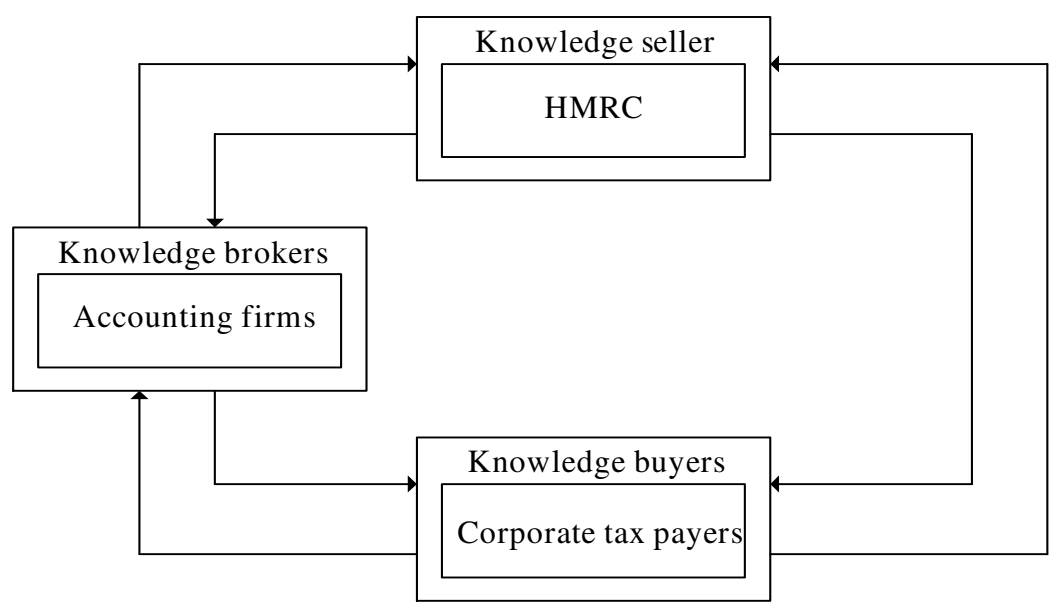

Other external influences:

Professional accounting associations

Industry and business lobbyists

Political parties

International organisations (e.g. OECD)

Supreme audit institutions (e.g. NAO)

Social and tax justice lobby groups 
TABLE 1

Intra-Organisational Knowledge Flows

Facilitators of Knowledge Sharing:

$\underline{\text { HMRC }} \quad \mathrm{AF} \quad \mathrm{CT}$

Electronic media

External sources

Internal technical manuals

Internal training

Intranet

Precedence files and databases

Training

Use of Subject Experts

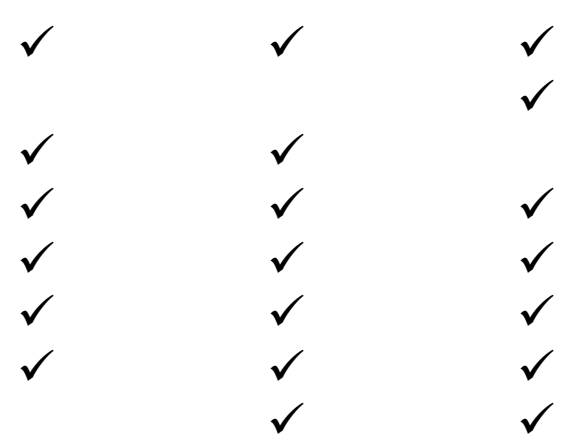

Barriers to Knowledge Sharing:

Anxiety in sharing too much

Confidentiality Issues

Information overload

Inadequate information technology

Insufficient incentives

Insufficient resources

Perceived lack of relevance to KS

Shortage of time

Legend:

Accounting Firms = AF; Corporate Taxpayers $=$ CT; HM Revenue $\&$ Customs $=$ HMRC

Knowledge Sharing = KS 


\section{APPENDIX \\ Interview Guide for Accounting Firms}

Goal: The aim of this interview is to help us obtain a better insight in knowledge flows about (changes in) tax legislation between HMRC, accounting firms, and corporate taxpayers

\section{Subjects and Confidentiality:}

Communication flows about new tax legislation between HMRC and the accounting firm, the role of accounting firms in this relationship, communication flows about new tax legislation within the organisation, and barriers to and facilitators of sharing knowledge. The identity of the interviewees will remain anonymous: their names will not be connected to the information that they provide during the interviews. We would like to tape the interview. Transcripts will be provided to interviewees.

\section{Main Questions:}

1. Introduction

2. Position of Interviewee

3. Knowledge Sharing HMRC - Accounting Firms

a. How would you describe the relationships between HMRC and your accounting firm (or firms in general)?

b. How does your Firm learn about new tax legislation from HMRC?

c. Is there any feedback from Firm to HMRC about new tax legislation?

4. External Barriers and Facilitators

a. What do you consider to be the most important barriers to sharing knowledge about new tax legislation between HMRC and accounting firms?

b. What do you consider to be the most important facilitators to sharing knowledge about new tax legislation between HMRC and accounting firms?

5. Knowledge Sharing within Firm

a. Which divisions or units within your organisation carry responsibility for learning about new tax legislation?

b. Through and to which divisions or units is new legislation communicated internally?

c. In which ways is new tax legislation shared internally?

d. How much freedom does your Firm have in interpreting, incorporating, and applying new tax knowledge?

6. Internal Barriers and Facilitators

a. What do you consider to be the most important barriers to sharing/creating knowledge about new tax legislation within your Firm?

b. What do you consider to be the most important facilitators to sharing/creating knowledge about new tax legislation within your Firm?

7. Knowledge sharing Accounting firms - Corporate Taxpayers (external Communication)

a. How do you think corporate taxpayers determine which sources to use to construct tax knowledge?

b. What is the role of accounting firms in communicating and applying new legislation in corporate firms?

c. How does the Firm inform clients about new tax legislation?

8. External barriers and facilitators

a. What do you consider the most important barriers to sharing knowledge about new tax legislation with (potential) clients?

b. What do you consider the most important facilitators to sharing knowledge about new tax legislation with (potential) clients?

9. Tax-legislation specific questions

a. We are particularly interested in the $R \& D$ tax credit. Has this new regime posed any particular issues for KM in your organisation? 